\title{
Analysis of different interface treatments between masonry of AAC blocks and reinforced concrete structure after uniaxial compression strength test
}

\author{
(1)D.S. Silva $\bowtie$, (D.G.P. Antunes \\ Department of Civil Engineering, University of the Extreme South of Santa Catarina, (Santa Catarina, Brazil) \\ $\checkmark$ dener.silveira@unesc.net
}

Received 05 August 2020

Accepted 25 February 2021

Available on line 30 July 2021

\begin{abstract}
Autoclaved aerated concrete (AAC) masonry is widely used in civil construction but requires further investigation. Hence, this experimental study evaluated three types of interface treatment between the reinforced concrete structure and AAC masonry, in scale, after a uniaxial compression resistance test. The types of interface treatment considered are reinforcement with steel bars, with rough polymeric cementitious mortar, and without treatment. The maximum load capacity, displacements, and occurrence of cracks were analysed. The results showed that the maximum individual load capacity did not significantly differ among the examined groups. However, the analysis of the displacements and cracks showed that the group with steel reinforcement had the smallest displacements and largest cracks. This behaviour is owing to the greater solidarity of forces conferred by steel reinforcement.
\end{abstract}

KEY WORDS: Brick; Mortar; Deformation; Metal reinforcement; Bond resistance.

Citation/Citar como: Silva, D.S.; Antunes, E.G.P. (2021) Analysis of different interface treatments between masonry of AAC blocks and reinforced concrete structure after uniaxial compression strength test. Mater. Construcc. 71 [343], e252. https://doi.org/10.3989/mc.2021.09920.

RESUMEN: Análisis de diferentes tratamientos de la interfaz entre la mampostería de bloques de hormigón celular y la estructura de hormigón armado tras el ensayo de resistencia a la compresión uniaxial. La mampostería de hormigón celular curado en autoclave (AAC) se utiliza ampliamente en la construcción civil, pero requiere una mayor investigación. Por eso, este estudio experimental evaluó tres tipos de tratamiento de la interfaz entre la estructura de hormigón armado y la mampostería de AAC, en escala, tras una prueba de resistencia a la compresión uniaxial. Los tipos de tratamiento de la interfaz considerados fueron el refuerzo con barras de acero, mortero cementante polimérico rugoso y sin tratamiento. Se analizó la capacidad de carga máxima, los desplazamientos y la aparición de fisuras. Los resultados mostraron que la capacidad de carga máxima individual no difiere significativamente entre los grupos examinados. Sin embargo, el análisis de los desplazamientos y las fisuras mostró que el grupo con refuerzo de acero tenía los menores desplazamientos y las mayores fisuras. Este comportamiento se debe a la mayor solidaridad de fuerzas que confiere el refuerzo de acero.

PALABRAS CLAVE: Ladrillo; Mortero; Deformación; Refuerzo metálico; Resistencia a la adherencia.

Copyright: (C2021 CSIC. This is an open-access article distributed under the terms of the Creative Commons Attribution 4.0 International (CC BY 4.0) License. 


\section{INTRODUCTION}

The search for more sustainable materials should consider the research in the field of construction. Because of the depletion in the natural deposits of raw materials, simple sustainable materials are required that exhibit durability with when maintained appropriately (1). Autoclaved aerated concrete (AAC) can be considered as an environmentally friendly material because of its potential for future applications (2). To efficiently satisfy the sustainability requirements, an AAC block was developed in the 1930s in Sweden and has since become popular worldwide because of its advantages (3).

Recently, with proven sustainable characteristics, AAC blocks are widely being as alternatives nowadays. In countries with extremely cold climate, where the temperature oscillates below zero for long periods of the day, the blocks are used for their thermal insulation capacity. Furthermore, the AAC material is popularly used in walls cuts fire under enclosed stairs $(2,4,5)$.

The American Standard (6) defines the AAC is a low-density cementitious product. The required raw materials for its production are Portland cement or similar cements, lime and gypsum as binders, quartz sand as aggregate - eventually replaced with similar products -, water, and an agent that generates macroscopic bubbles or voids. All materials are mixed, moulded, and cut, after which the blocks undergo the autoclaving process and maintained at a high pressure $(1.2 \mathrm{MPa})$ and temperature $\left(200^{\circ} \mathrm{C}\right)$ for a period of $12 \mathrm{~h}$. The blocks acquire their final characteristics of resistance and dimensional stability through this process.

The authors (7) affirm that when compared to a concrete block with similar dimensions, the AAC presents a lower capacity of resistance to compression. This effect is caused by its accentuated macroscopic porosity. The AAC has high porosity owing to the volume of air voids (8) and approximately $70-80 \%$ of the component volume (9). However, using these blocks for masonry is a rational method of construction because of its larger dimensions and weight, which cause a significant increase in productivity and lessen the workforce (4). Ref (10) specifies that the minimum dimensions of an AAC block are $200 \times 200 \times 75 \mathrm{~mm}$ (length $\times$ height $\times$ thickness), and its specific weight is approximately $450-650 \mathrm{~kg} / \mathrm{m}^{3}$.

The AAC blocks employ empirical principles in construction project (2), which leads to pathological manifestations, such as cracks, detachments of mortars for laying and covering, cracks around frames, and cracks in the interface with other components and/or elements. The filling walls require compressive strength, tensile strength, and shear strength at their interfaces, particularly with the correspond- ing concrete structure (11). As the filling walls are a composition of different components (blocks and mortar) and masonry panels connected to the concrete structures, it is essential to investigate the prevention of pathological manifestations.

The interface between the masonry and structure is a point of weakness in civil construction. References (12-14) reported that hygroscopic movement, pressure on foundations, and deflections in the structural system can cause stresses on the masonry elements, as a function of the type of material used and movements caused. If the aforementioned stresses are not compatible with the type of masonry, certain precautions must be taken to avoid cracking or displacement of the concrete structures.

Several types of cracks are found in this region with greater or lesser severity depending on the amount of load applied to the masonry and deformations caused to it (15). Considering the cracks, differentiated hygrothermal movements are frequently found in buildings $(5,15)$. The edges of non-structural masonry, close to the structural elements, are mostly affected by cracks and detachments caused by variations in humidity and temperature. These movements are mainly found in the facades of buildings.

According to (16), when considering walls that are less susceptible to movement, such as ground buildings, internal walls, and small facade areas, masonry is not required to be anchored to the concrete structure, and it can only be connected with roughcast (rolled roughcast in Brazil). This, in turn, can be produced using conventional mortar or polymer cement mortar (PCM).

For an effective anchorage in the structure, reinforcements with steel rebar can be employed that (17) are connections made using steel bars with anchors to the concrete structure. They acquire adherence by being attached to the pillars using concrete or fixed at a later stage using epoxy resin or polyester. Alternative to using reinforcement with steel rebar, a connection is created using electrically welded wire mesh fixed to the concrete through pins, which provides considerable adherence to the mortar for laying the blocks (18).

Considering the walls constructed using AAC blocks, the standards $(19,20)$ for the execution of walls without structural function, determine that the walls require anchoring in the structure only in specific situations, such as large spans without locking or stretches of structure for balance. According to the referenced standards, if such situations occur, bonding with the structure can be achieved using steel rebar reinforcement when the blocks are set using PCM. Similarly, it can be achieved with steel rebar reinforcement or electro-welded mesh when of the blocks are set using conventional mortar, as proposed by $(19,20)$. 
This study aims to evaluate the interface between the reinforced concrete structure and AAC masonry, in scale, after the uniaxial compression resistance test. Three types of treatment were used at the interface: reinforcement with steel rebars, with rough PCM, and without treatment (filling with the laying mortar itself).

\section{MATERIALS AND METHODS}

To evaluate the deformations generated at the interface between the reinforced concrete structure and autoclaved aerated concrete block masonry, three groups of reinforced concrete structures with AAC masonry closure were employed. Each group had their corresponding interface treatment solutions in reduced dimensions, called "walls". However, to verify the stability of the walls during the compression test, two identical structures "prototypes", which differ only in thickness, were previously prepared to verify the slenderness index and rotation in order to select a specific dimension.

The codification and differentiation between the types of walls and prototypes are listed in Table 1.

The study methodology consisting of the construction of the structures and execution of destructive tests is presented as a flowchart in Figure 1.

The dimensions of the walls are as follows: height of $270 \mathrm{~cm}$, length of $300 \mathrm{~cm}$ and a varying thickness of $15 \mathrm{~cm}$ and $22.5 \mathrm{~cm}$. All dimensions have been reduced three times than those of the original walls to test the efficiency of the model. This scale was incorporated from the commercial thickness dimensions of AAC blocks of thicknesses $5 \mathrm{~cm}$ and 7.5 $\mathrm{cm}$, respectively. The results of this study cannot be extended to a real model without further studies.

The ACC Blocks used in this study was supplied by a company located in the south of Santa Catarina state. According to the supplier's specification, it belongs to class $\mathrm{C} 15$, whose dry apparent density is less than $500 \mathrm{~kg} / \mathrm{m}^{3}$. The minimum average compressive strength is $1.5 \mathrm{MPa}$ and minimum isolated value is $1.2 \mathrm{MPa}$. The dimensions of the blocks were based on the scale that governs the dimensions of the experiment; hence, the original measure of the blocks was $60 \times 30 \times 5$ or $7,5 \mathrm{~cm}$ became blocks of $20 \times 10 \times 5 \mathrm{~cm}$ and $20 \times 10 \times 7.5 \mathrm{~cm}$ (Figure 2), and half blocks for tying the wall were employed. All cuts were performed by a specialised company, thus avoiding inaccuracies in the cuts.

Owing to the reduced size of the prototype and complexity of executing a structure with small dimensions, small gravel was used as a coarse aggregate. As a fine aggregate, medium washed sand and Portland cement (CP II-Z) were used as binder in traces 1:2.99:3.01:0.7 for the concrete. This trace was dosed to obtain a resistance of approximately $15 \mathrm{MPa}$ to avoid high rigidity in the concrete com-

TABLE 1. Codification and definitions

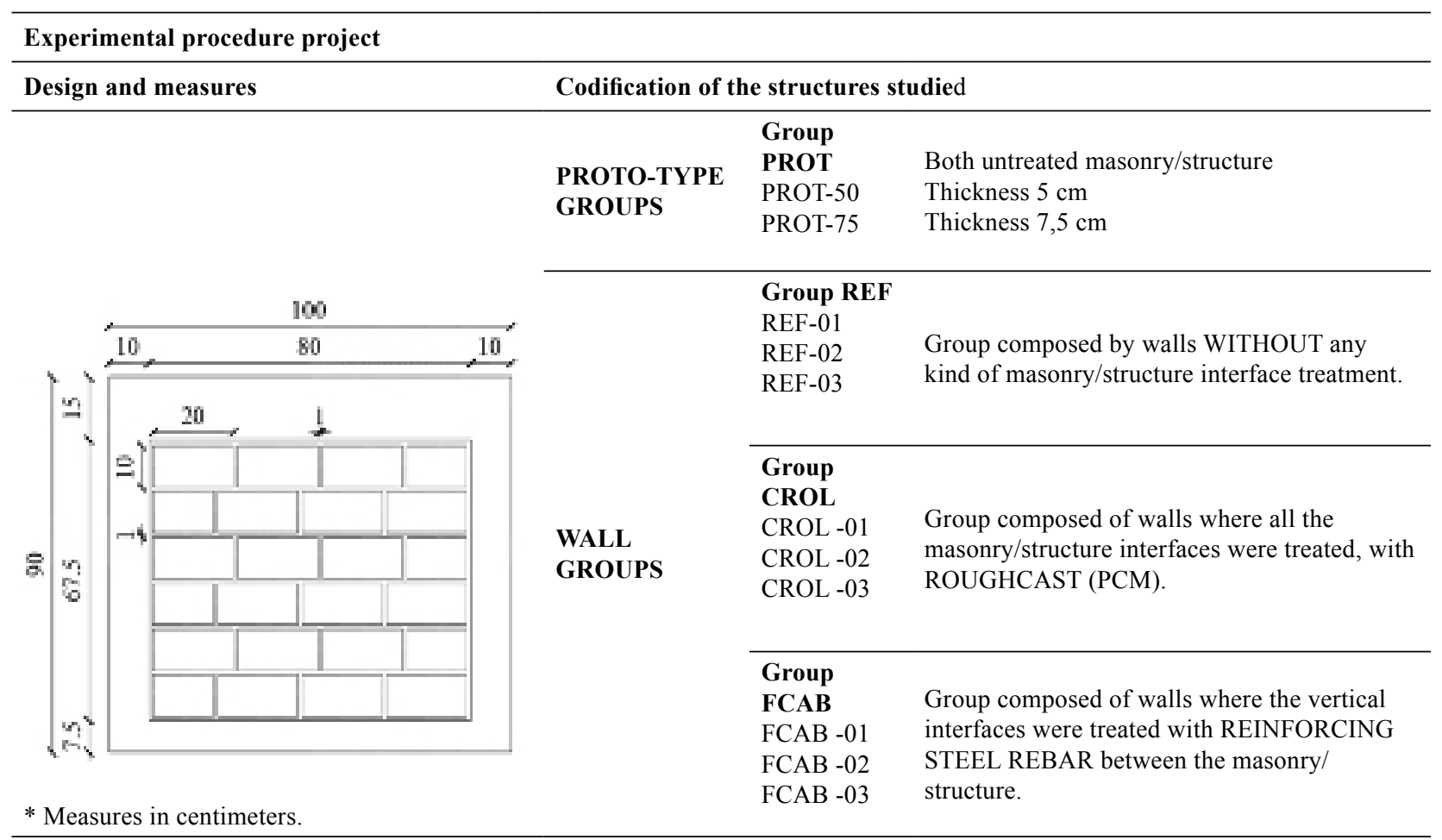




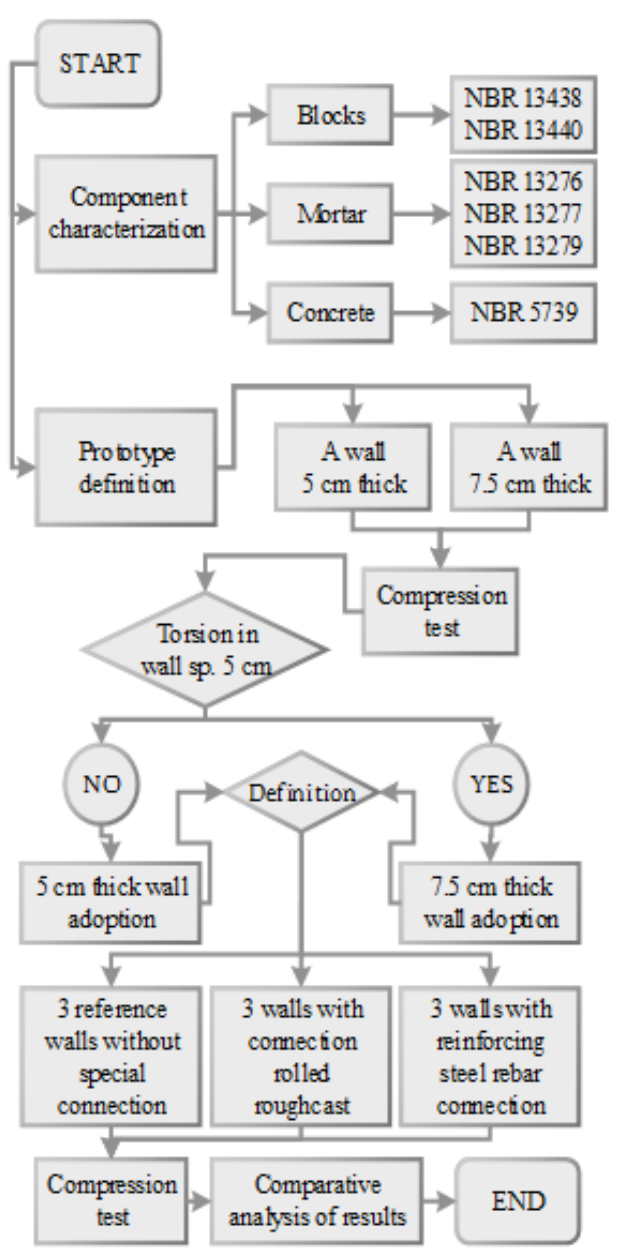

FiguRE 1. Flowchart of activities.

ponent. The characterisation of the aggregates was performed according to the standards (21-23), as shown in Table 2.

To obtain a lesser rigid structure to observe the interaction between the components while considering the minimum parameters established by (24), steel rebars with a thickness of $5 \mathrm{~mm}$ (fy $=600 \mathrm{MPa})$ were used for all the reinforced concrete components; the structures used four longitudinal rebars and stirrups with a spacing of $15 \mathrm{~cm}$. To cover the rebars, the same requirement of reduced dimensions was maintained for the adaptation to the model, thus, $1 \mathrm{~cm}$ of covering was adopted.

The concrete structures were moulded in Pinus elliottii moulds (Figure 3a), placed horizontally on plastic sheets, and the group was positioned on rectified floors. The structures were demoulded and placed vertically after 7 days (Figure 3b), and the masonry was laid among the already rigid structures (Figure $3 \mathrm{c}$ ).

In the FCAB group, interface treatment of the masonry structure (Figure 4) was conducted using a steel rebar with a diameter of $4.2 \mathrm{~mm}(\mathrm{fy}=600 \mathrm{MPa})$ and anchored with a hook of length $5 \mathrm{~cm}$ inside the reinforced concrete pillars and that of $15 \mathrm{~cm}$ in the horizon-
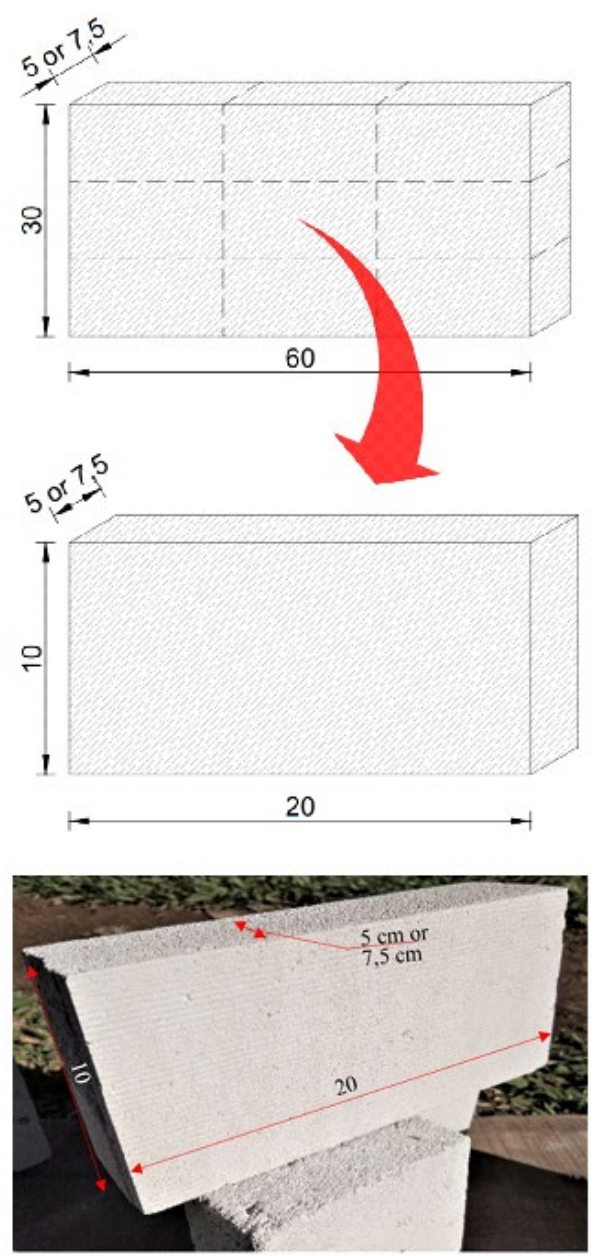

FIGURE 2. Detail of dimensions of autoclaved aerated concrete block.

TABLE 2. Aggregate characterization.

\begin{tabular}{lll}
\hline Index & Medium sand & Gravel \\
\hline Fineness modulus & 2.37 & 5.89 \\
\hline Nominal maximum size $(\mathrm{mm})$ & 2.40 & 9.50 \\
\hline Dry unit weight $\left(\mathrm{kg} / \mathrm{m}^{3}\right)$ & 2364.91 & 2907.73 \\
\hline Unit weight $\left(\mathrm{kg} / \mathrm{m}^{3}\right)$ & 1580.70 & 1474.67 \\
\hline
\end{tabular}

tal mortar joint. The rebar reinforcement was applied to each of the two rows of blocks, thus totalling to three rebars on the left side and three more on the right side.

In the second group of walls called the CROL group, polymeric cementitious mortar was applied on the internal face of the pillars that would have contact with the AAC panels. PCM was applied using a texture roller to generate roughness and increase adherence between the structure and masonry. The technical specifications of the PCM are listed in Table 3.

In the REF group, the internal face of the pillars did not undergo surface treatment. In this group, the AAC column and masonry interface was filled with the mortar used for block settlement. 
(a)

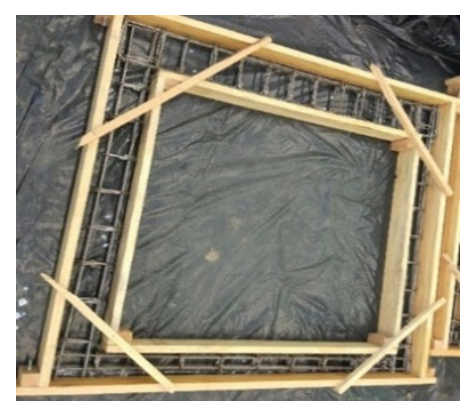

(b)

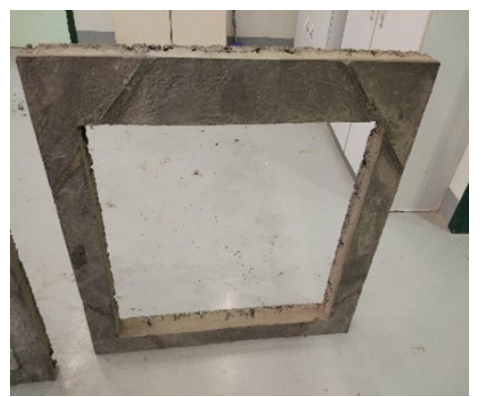

(c)

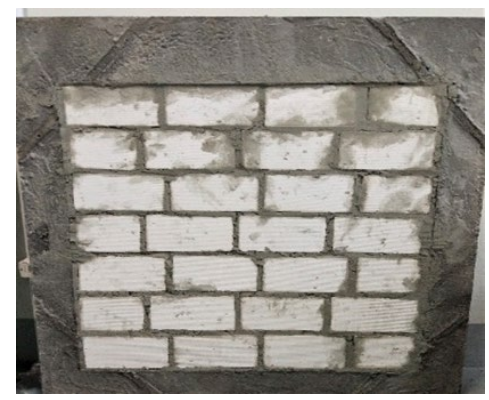

FIGURE 3. Stages of experimentation: (a) Wood molds, (b) concrete frame, (c) structure filled by masonry.

(a)

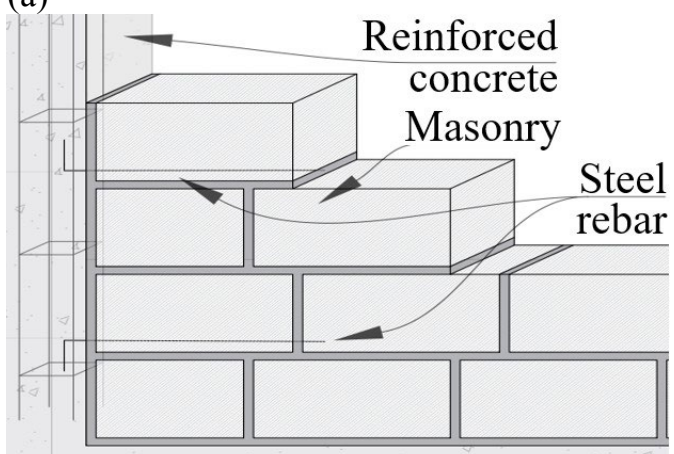

(b)

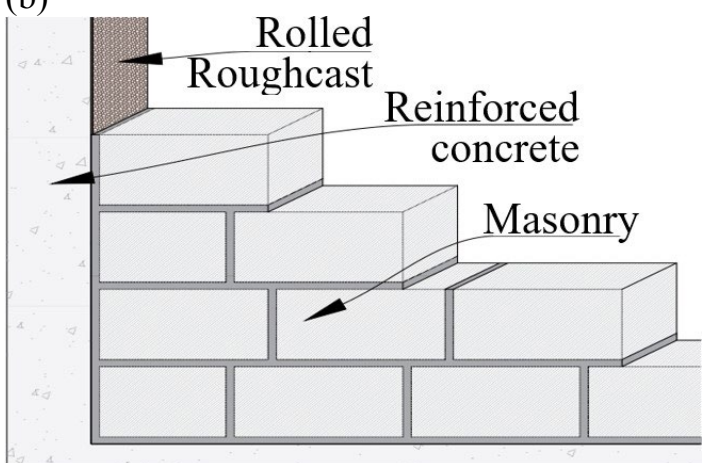

FIGURE 4. Illustration of the connecting elements: (a) steel rebar reinforcement, (b) rolled roughcast (PCM).
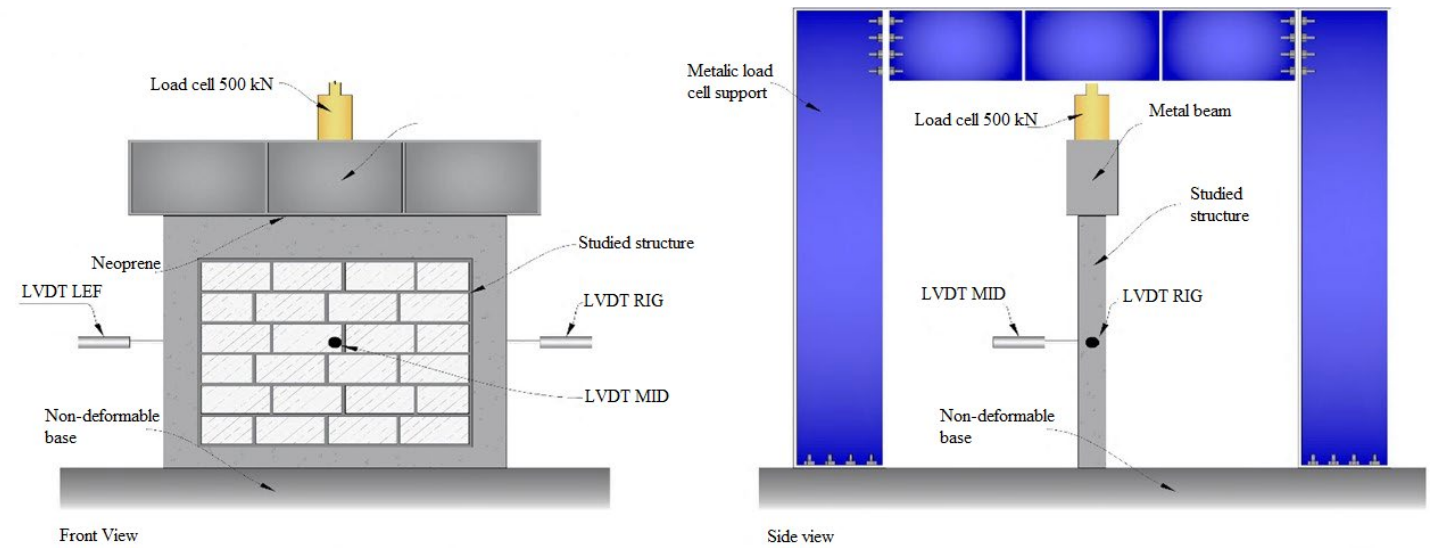

FigURE 5. Front and side illustration of the distributed load compression test.

TABLE 3. Technical specifications of the rolled roughcast.

\begin{tabular}{ll}
\hline Index & Value \\
\hline Apparent density & $1.6 \mathrm{~g} / \mathrm{cm}^{3}$ \\
\hline Fresh density & $1.9 \mathrm{~g} / \mathrm{cm}^{3}$ \\
\hline Adhesion strength on concrete at 28 days & $\geq 0.5 \mathrm{MPa}$ \\
\hline
\end{tabular}

(Source: Supplier, 2019)

The dimensions of the AAC blocks were verified through (10), and the mechanical resistance and dry apparent density was verified according to (25). The block laying mortar was tested for compression and traction in bending following (26), water retention according to (27), and consistency as per (28).

After curing for 28 days, the walls were subjected to destructive compression, as shown in Figure 5.

The uniaxial compressive strength test of the walls was performed on a reaction frame. The walls were positioned on a gantry such that their centre of gravity was aligned with the load axis of the press. The tests were performed using a HBM U10M load cell with a maximum capacity of $500 \mathrm{kN}$. The walls were subjected to increasing loads up to the walls' breaking limit. During the test, the applied tension in the gross area was gradually raised to $(0.05 \pm 0.01) \mathrm{MPa} / \mathrm{s}$, as indicated by (29). The application of load on the walls 


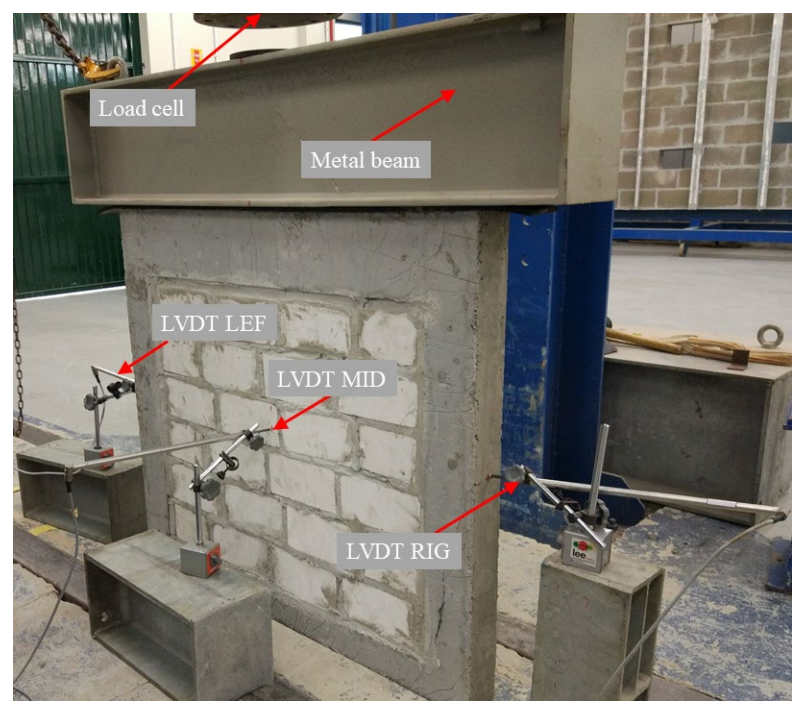

FIGURE 6. Wall positioning of LVDTs.

was terminated at the start of the gradual loss of load. The load applied by the cell was applied on a steel beam of ASTM A572 Grade 50 with a minimum yield limit of $350 \mathrm{MPa}$ and an elastic modulus of $200 \mathrm{GPa}$ to distribute the load on the walls, and consequently, simulate the effects generated. The beam is a $\mathrm{W}$ profile with dimensions of approximately $25 \times 15 \times$ $130 \mathrm{~cm}$ (height $\times$ width $\times$ length) with a mass of 57 $\pm 2.5 \mathrm{~kg}$. A piece of neoprene was used between the steel beam and wall to avoid possible load concentrations because of a laboratory floor situated at the base of the wall, which was considered not deformable for this test. Figure 6 presents a wall before adding the load.

The results were evaluated by analysing the horizontal displacements. Hence, linear variable displacement transducers (LVDT) with a nominal measuring range of $0-100 \mathrm{~mm}$ were used and connected to the Quantum - MX840 8 channel data acquisition system, which uses the Catman Easy ${ }^{\circledR}$ software; the system and software were sourced from $\mathrm{HBM}^{\circledR}$ branded. Three LVDTs were used in three different positions, as illustrated in Figure 6. The "LVDT LEF" and "LVDT RIG" were located parallel to the wall while the "LVDT MID" was located perpendicular to the wall; all LVDTs were of average masonry height.

\section{RESULTS AND DISCUSSIONS}

The concrete used in the structures were tested for compression and produced mean values of 14.47 $\mathrm{MPa}$ with a standard deviation of 2.87 . These results indicate that the concrete used in the structures demonstrated the required strength, as the component achieved the expected values of this study.

Table 4 presents the results corresponding to the laying mortar, water retention, consistency in fresh state, and compressive and tensile strength for bending.
TABLE 4. Characterization of the laying mortar.

\begin{tabular}{llll}
\hline $\begin{array}{l}\text { ABNT } \\
\text { Standard }\end{array}$ & Index & $\begin{array}{l}\text { Average } \\
\text { result }\end{array}$ & $\begin{array}{l}\text { Standard } \\
\text { deviation }\end{array}$ \\
\hline $\begin{array}{l}\text { NBR } \\
\text { 13277:2005 }\end{array}$ & Water retention & $96 \%$ & - \\
\hline NBR & Consistency index & $213 \mathrm{~mm}$ & - \\
\hline 13276:2016 & Flexural tensile & 1.72 & 0.29 \\
NBR & strength at 28 days & $\mathrm{MPa}$ & \\
\cline { 2 - 4 } 13279:2005 & $\begin{array}{l}\text { Compressive strength } \\
\text { at 28 days* }\end{array}$ & $\begin{array}{l}\text { M.83 } \\
\text { MPa }\end{array}$ & 0.31 \\
\hline
\end{tabular}

* Value corrected according to standard.

Table 4 shows that the mortar demonstrates high water retention, which is an important property when used in AAC block masonry considering its porosity. According to (26), the compression results should exhibit a standard deviation of less than 0.5 ; if the value is greater than 0.5 , the discrepant values must be excluded until the required value is obtained, with respect to a sample size of greater than or equal to four samples. The compression test was performed on 10 samples, but two samples were excluded, with eight valid.

The AAC blocks underwent dimensional tests, where a dimensional variation greater than the maximum tolerances specified by (10) was not observed. The other characterisations of the blocks are listed in Table 5 .

TABLE 5. Characterization of AAC blocks.

\begin{tabular}{llll}
\hline Standard & Index & $\begin{array}{l}\text { Average } \\
\text { result }\end{array}$ & $\begin{array}{l}\text { Standard } \\
\text { deviation }\end{array}$ \\
\hline $\begin{array}{l}\text { ABNT } \\
\text { NBR }\end{array}$ & $\begin{array}{l}\text { Resistance to axial } \\
\text { 13440:2013 }\end{array}$ & 2,17 & 0.32 \\
\cline { 2 - 4 } & Dry bulk density $\left(\mathrm{kg} . \mathrm{m}^{-1}\right)$ & 492.16 & 7.31 \\
\hline & Water absorption & $69 \%$ & 6.73 \\
\hline
\end{tabular}

Parallel to the component characterisation stage, the two structures of the prototype group were tested to define the thickness to be adopted in all the walls in this study. Figure 7 shows a greater deformation in the PROT-50 that generated the destabilisation of this prototype. This effect was not noticed in the PROT-75, even after the complete rupture of the concrete structure.

The data collected by the LVDT positioned at the centre of the prototypes and plotted in Figure 8 were consistent with the effects visualised in the prototypes (Figure 7), thus demonstrating that the prototype (PROT-50) with a thickness of $5 \mathrm{~cm}$ obtained a rotation around the axis of load application. 
The walls with thickness of $7.5 \mathrm{~cm}$ (PROT-75) were chosen for the tests and comparison of results.

For the initial hypothesis, we investigated the variation in the amount of load supported by the specimens to observe the differences caused by the greater solidarisation of the entire body of the wall.

The results show that the maximum load capacity of each of the walls (Table 6) did not significantly differ in the analysed groups, and all the walls remained stable during the prototype test (Figure 7b). The maximum load was considered when the maximum press load was attained, followed by a gradual loss of load.

TABLE 6. Maximum load bearing capacity of the Walls.

\begin{tabular}{llll}
\hline \multirow{2}{*}{ Index } & \multicolumn{3}{l}{ WALL groups $\left(\mathrm{kN} . \mathrm{m}^{-1}\right)$} \\
\cline { 2 - 4 } & REF & CROL & FCAB \\
\hline 01 & 302.7 & 329.1 & 301.5 \\
\hline 02 & 340.7 & 282.1 & 313.3 \\
\hline 03 & 304.8 & 245.7 & 326.2 \\
\hline Average & 316.0 & 285.6 & 313.6 \\
\hline Standard deviation & 21.4 & 41.8 & 12.4 \\
\hline
\end{tabular}

Table 6 shows two slightly discrepant values in the CROL group, demonstrating the two lowest load val-

(a)

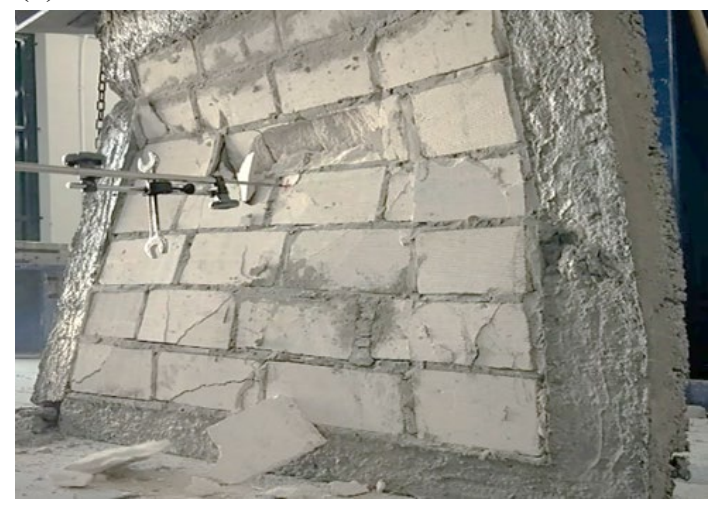

ues obtained in the tests. These values cannot be considered as the worst performance without conducting further tests because the remaining value pertaining to the group was high. However, to validate the values presented in the table, the analysis of variance (ANOVA) between the groups was performed. Then, it could be stated with $95 \%$ reliability $(\mathrm{P}=0.394)$ that statistically, the walls are indistinguishable in terms of resistance to the maximum load bearing capacity. Therefore, it was verified that the type of interface treatment between the reinforced concrete structure and masonry with AAC blocks did not influence the value of the maximum breaking strength load. The maximum load of breaking strength refers to the maximum value obtained, from which the load drop of the walls begins. Alvarenga (30) reported that in his analysis of the presence of steel rebar in the interface region between the metallic gantry and masonry with AAC blocks, after a resistance test of the assemblage of the rebar did not contribute to the increase of the breaking load resistance. Adherence between the elements (structure and masonry) may cause a small increase in resistance, mainly to traction efforts. However, interface detachment occurs after overcoming this level of tension (30).

From the beginning of the cracking of the masonry (Figure 9), certain tendencies were already iden-

(b)

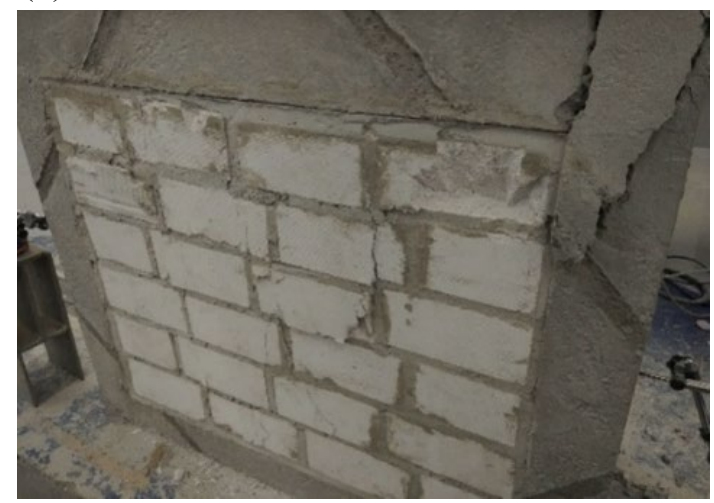

FigurE 7. Prototypes after axial compression test: (a) $5 \mathrm{~cm}$ thick (PROT-50), (b) $7.5 \mathrm{~cm}$ thick (PROT-75).

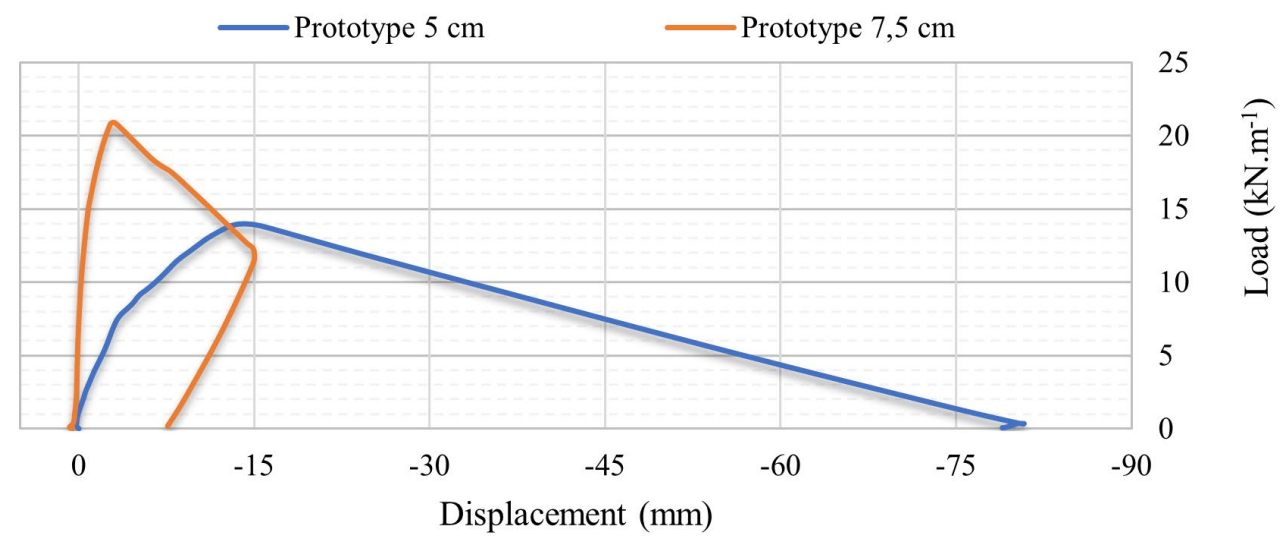

FIGURE 8. Prototype load/shift graph, LVDT located in the center of the wall. 
tified by (11); non-structural masonry, when submitted to the distributed forces of compression from the concrete structures, tend to crack vertically, parallel to the application of the load. A similar comportment was also identified by (31) while evaluating another masonry type, however opposite than comportment observed by (32) while evaluating a fragile material.

Figure 9 shows that the central cracks developed in a similar way in all groups of walls, but certain differences were found between the masonry interface and structure. The cracks appeared for all groups around $100 \mathrm{kN} / \mathrm{m}$. However, at loads close to $100 \mathrm{kN} / \mathrm{m}$, the walls of the CROL group presented cracks in smaller numbers and with smaller thickness and length of the openings when compared to those of the other groups. This may be owing to the characteristics of the mortars used, considering that, conventionally, PCMs exhibit a lower modulus of elasticity than that of conventional mortars. This facilitates the distribution of tensions and resistance for lower loads.

The walls of the REF group demonstrated early interface detachment when compared to the other two types. This may be owing to lower adhesion between the masonry with AAC blocks and wall structure than that of the FCAB and CROL groups. At the end of the test, the walls of the FCAB group had the highest number of cracks close to the structure. This behaviour was due to the greater adhesion of the reinforcement with the structure inserted in the tying interface because of the lowest displacements of the group. Figure 10a and Figure 10b show the displacements during the load application.

Figure 10(a) and Figure 10(b) demonstrate that at approximately $100 \mathrm{kN} / \mathrm{m}$, the largest displacements were initiated mainly in the CROL group, which suffered a strong discontinuity of the load-displacement curve around the aforementioned value. This demonstrates a more fragile behaviour (33) when compared to the other walls.
According to (30), the structural element filled with sealing masonry from the addition of load exhibits three stages. The first stage consists of a monolithic behaviour, where the group resists the loads. In the second stage, the masonry desolidarises the structure. In the third stage, the masonry begins to rupture, followed by the total rupture of the system. In this study, the first stage was between 60 and $80 \mathrm{kN} / \mathrm{m}$, and the second stage was between 80 and $130 \mathrm{kN} / \mathrm{m}$. In the second stage, the smallest displacements of the walls of the FCAB group were observed because of the greater solidification, thus prolonging the monolithic effect.

In the third stage, the biggest structural damage occurs in the walls, as shown in Figure 11. Figure 11 shows the average displacements in the centre of the walls. It was verified that the FCAB group exhibits the smallest displacements. Furthermore, the CROL and FCAB dislocations occur at approximately $90 \mathrm{kN} / \mathrm{m}$.

Considering total displacement, the walls of the FCAB group obtained the lowest displacement values throughout the test. This shows that the reinforcement with steel rebar solidified the loads between the reinforced concrete pillars, minimising such effects.

However, considering the amount of displacement at the moment of maximum load of each wall, as shown in Table 7 , it can be confirmed with $95 \%$ reliability $(\mathrm{P}=0.085)$ that the walls are statistically indistinguishable, which was proven using ANOVA.

Evaluating the displacements of stage 3 rupture according to (30) through Figure 9 and Figure 10, and the mean displacement values at the moment of rupture (Table 7), it was found that even in the absence of statistical evidence, the walls of the CROL group showed higher mean movements when compared to the other groups. This may be caused by the more abrupt rupture between the reinforced concrete interface and masonry. This result differs from that obtained by (30) that demonstrated a similar behaviour between the interface treatments between steel rebar and PCM. (a)

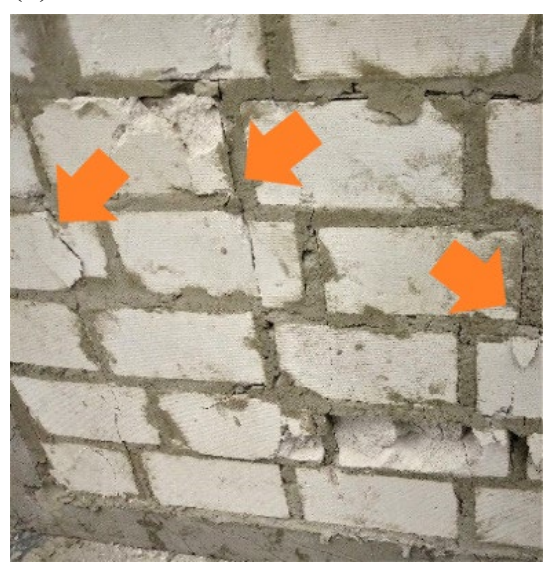

(b)

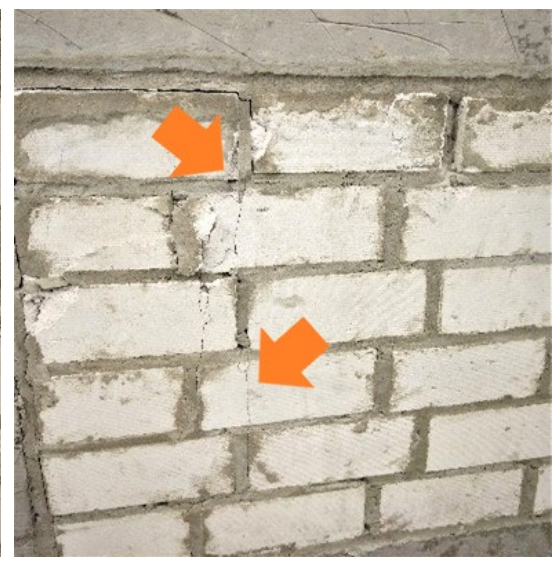

(c)

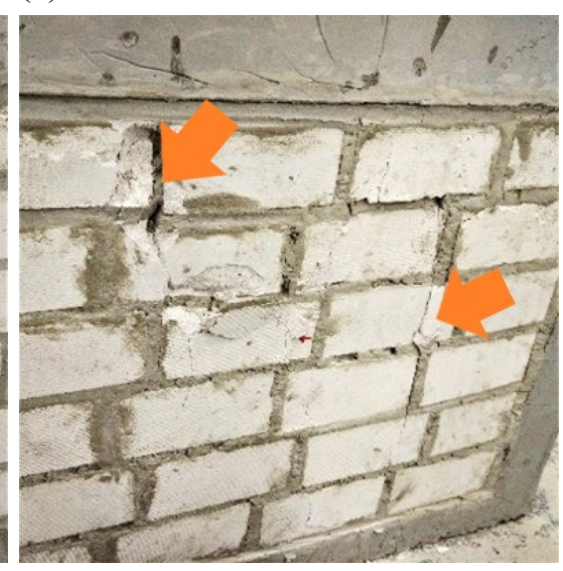

FIGURE 9. Vertical cracks in AACB masonry: (a) REF cracks, (b) CROL cracks, (b) FCAB cracks. 
(a)

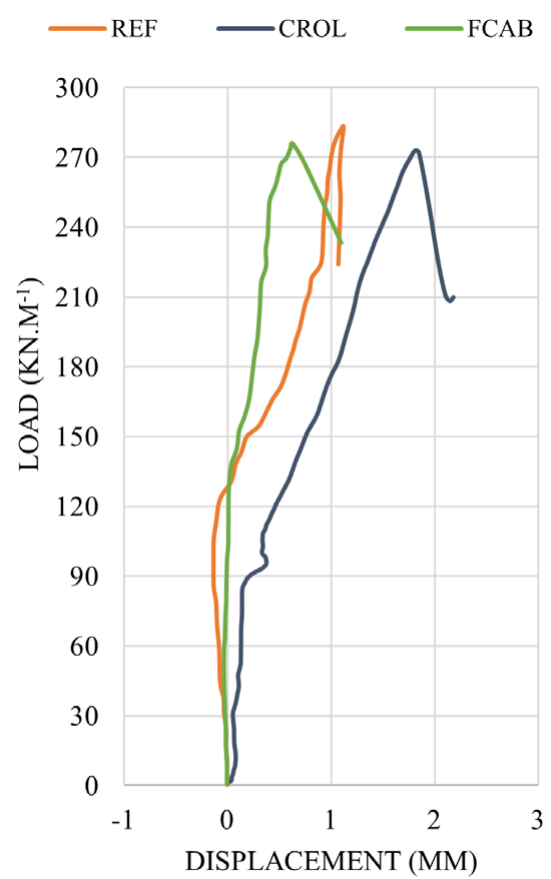

(b)

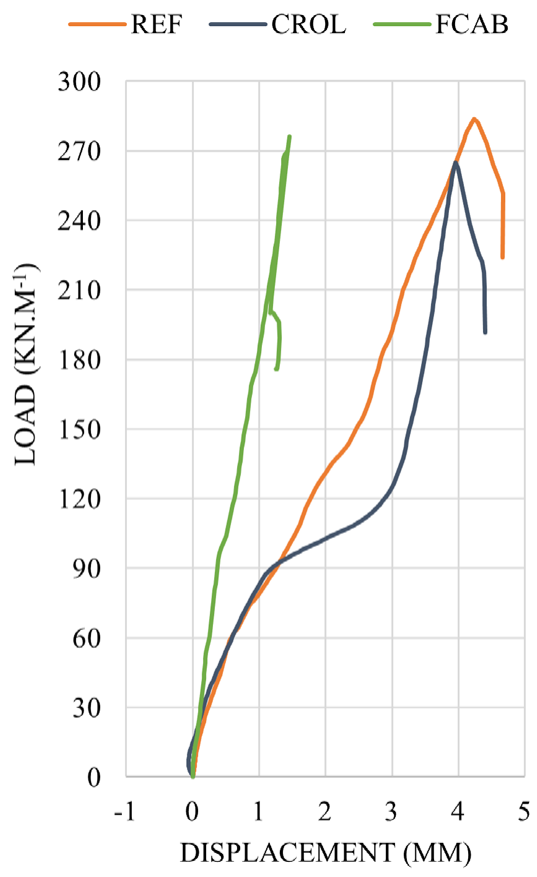

FIGURE 10. Average displacement and load values: (a) LVDT positioned to the left of the structure, (b) LVDT positioned to the right of the structure.

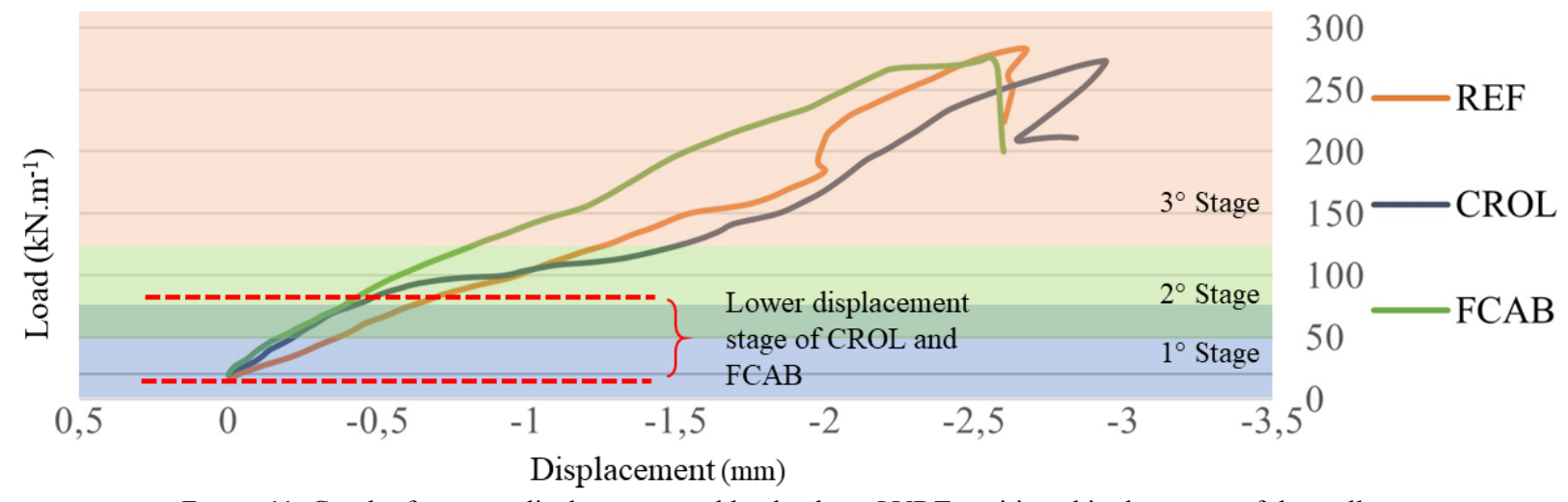

FIGURE 11. Graph of average displacement and load values, LVDT positioned in the center of the wall.

TABLE 7. Displacement at the moment of wall rupture (masonry and structure).

\begin{tabular}{|c|c|c|c|c|c|c|c|c|c|}
\hline \multirow{4}{*}{ Index } & \multicolumn{9}{|c|}{ WALL groups (mm) } \\
\hline & \multicolumn{3}{|l|}{ REF } & \multicolumn{2}{|l|}{ CROL } & \multicolumn{4}{|l|}{ FCAB } \\
\hline & LVDT & LVDT & LVDT & LVDT & LVDT & LVDT & LVDT & LVDT & LVDT \\
\hline & LEF. & MID. & RIG. & LEF. & MID. & RIG. & LEF. & MID. & RIG. \\
\hline 01 & 2.219 & -2.635 & 5.731 & 1.208 & -3.502 & 2.997 & 0.349 & -2.91 & 0.7637 \\
\hline 02 & 0.825 & -2.083 & 1.626 & 4.230 & -2.907 & 4.041 & 0.972 & -1.615 & 2.209 \\
\hline 03 & 0.588 & -3.086 & 6.942 & 1.125 & -4.476 & 5.514 & 1.879 & -1.97 & 1.428 \\
\hline Average & 1.211 & -2.601 & 4.766 & 2.188 & -3.628 & 4.184 & 1.067 & -2.165 & 1.467 \\
\hline Standard deviation & 0.88 & 0.50 & 2.79 & 1.77 & 0.79 & 1.26 & 0.77 & 0.67 & 0.72 \\
\hline Standard deviation mean & 1.39 & & & 1.27 & & & 0.72 & & \\
\hline
\end{tabular}




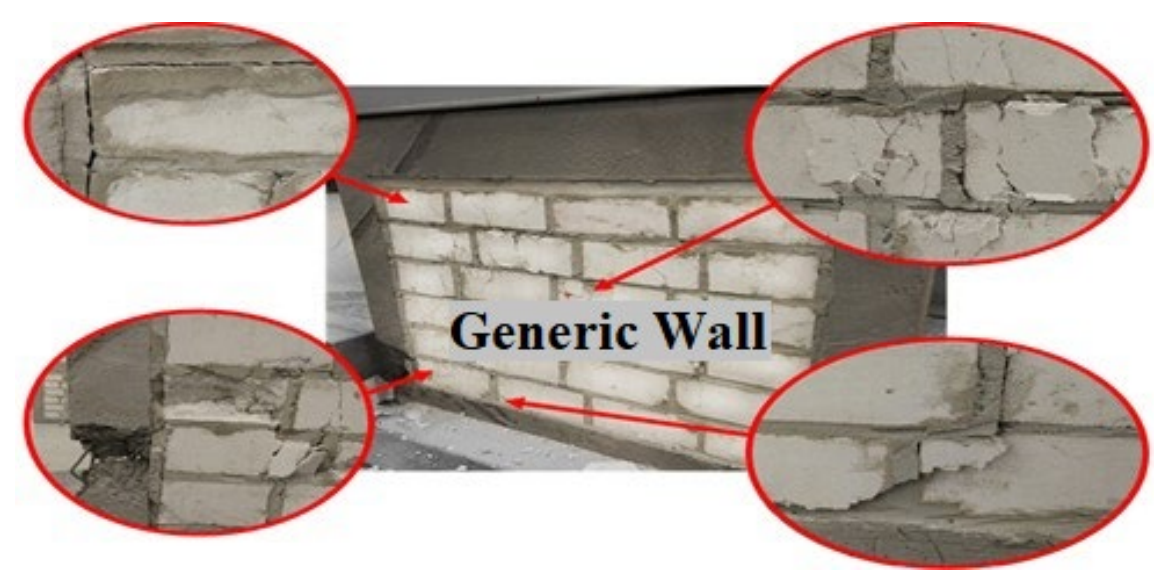

FIGURE 12. Details of cracks and cracks in walls after testing.

To demonstrate the most important types of cracks and crevices in masonry, Figure 12 presents a generic wall of the study with four enlarged details. These details demonstrate the rupture of the AAC blocks at several points, which was observed in all walls.

The top left detail of Figure 12 demonstrates an increase in the interface between the concrete structure and masonry in the CROL group. Particularly for this group, the vertically laid mortar detached from the block and continued to adhere to the structure. This was not observed in the other two groups of walls. This detachment of the mortar from the AAC blocks was studied by (34), and a good adhesion results were obtained in the joints filled with PCMs when compared to conventional mortar mixtures. The results are different from the results obtained in this study.

\section{CONCLUSIONS}

The following are the conclusions drawn from the obtained results. In general, all wall groups perform similarly when evaluating the maximum amount of load carried by the structures. The CROL group exhibits extreme discrepancies in this regard - the two smallest resistances, which are not statistically differentiable. Hence, further tests should investigate such differentiation. This circumstance indicates that the masonry with techniques of interface with the structure maintains a similar performance as that of the CROL group.

However, although the maximum load increase is not sufficiently distinct to distinguish the groups, considerable differences in the displacement were observed during the tests. The movements of the FCAB group were characterised as inferior, while the walls of the CROL group obtained even greater displacements than the walls of the REF group. These events occur in stages prior to the maximum load. At this time, according to ANOVA, the displacements become statistically indistinguishable.

It may be inferred that the masonry began show- ing signs of rupture around $100 \mathrm{kN} / \mathrm{m}$ with the appearance of cracks in the interface between the reinforced concrete structure and masonry. At this load, the walls of the REF group exhibited cracks superior to those of the other groups, while the walls of the CROL group exhibited the smallest cracks.

In summary, considering the displacements obtained, the FCAB group had a greater approximation of the monolithic behaviour than the others, which was observed as the lesser deformation in the period of masonry rupture.

Therefore, it is concluded that this study provides more significant results during the first-third of the load application of the tests; the effects were minimised and became indistinguishable from each other towards the end. Furthermore, it is perceived that the study generated qualitative variables of visual aspect. Future studies may consider other variables, such as the adoption of greater strength for the concrete of the structures, hygrothermal movements, or application of transverse loads to the walls. The results obtained in this study belong to a scale model and are not exportable to a real model, at least without a comparison between the two models to prove their effectiveness.

\section{AUTHOR CONTRIBUTIONS:}

Conceptualization: D.S. Silva, E.G.P. Antunes. Data curation: D.S. Silva. Formal analysis: E.G.P. Antunes. Investigation: D.S. Silva, E.G.P. Antunes. Methodology: D.S. Silva, E.G.P. Antunes. Project administration: D.S. Silva. Resources: D.S. Silva, E.G.P Antunes. Software: D.S. Silva. Supervision: D.S. Silva, E.G.P. Antunes. Validation: D.S. Silva, E.G.P. Antunes. Visualization: D.S. Silva, E.G.P. Antunes. Roles/Writing, original draft: D.S. Silva, E.G.P. Antunes. Writing, review \& editing: D.S. Silva, E.G.P. Antunes.

\section{REFERENCES}

1. Ismaeel,W.S.E.;Ali,A.A.M.(2020)Assessmentofeco-rehabilitation plans: case study 'Richordi Berchet' palace. Clean. Produc. 259, 120857. https://doi.org/10.1016/j.jclepro.2020.120857.

2. Jerman, M.; Keppert, M.; Výborný, J.; Černý, R. (2013) Hygric, thermal and durability properties of autoclaved 
aerated concrete. Construc. Build. Mat. 41, 352-359. https:// doi.org/10.1016/j.conbuildmat.2012.12.036.

3. Kalpana, M.; Mohith, S. (2020) Study on autoclaved aerated concrete: Review. Mater. Today: Proceed. 22 [3], 894-896. https://doi.org/10.1016/j.matpr.2019.11.099.

4. Chen, Y.; Peng, M.; Zhang, Y.; Liu, Y. (2013) Mechanical properties of autoclaved aerated concrete with different densities. Advanc. Civil Eng. Mat. 2 [1], 441-456, https://doi. org/10.1520/ACEM20130063.

5. Trindade, A.D.; Coelho, G.B.A.; Henriques, F.M.A. (2021) Influence of the climatic conditions on the hygrothermal performance of autoclaved aerated concrete masonry walls. J. Build. Eng. 33, 1-11. https://doi.org/10.1016/j. jobe.2020.101578.

6. ASTM International. C1693-11: (2017) Standard Specification for Autoclaved Aerated Concrete (AAC). 7 ed. West Conshohocken, USA, ASTM.

7. Ferretti, D; Gherri, B; Michelini, E. (2018) Eco-mechanical indexes for sustainability assessment of AAC blocks. IOP Conference Series: Mat. Scie. Eng. 442, 012011. https://doi. org/10.1088/1757-899x/442/1/012011.

8. Narayanan, N.; Ramamurthy, K. (2000) Structure and properties of aerated concrete: a review. Cem. Concr. Compos. 22 [5], 321-329. https://doi.org/10.1016/S0958-9465(00)00016-0.

9. Subash, M.C.G.; Satyannarayana, V.S.V.; Srinivas, J. (2016) Aerated autoclaved concrete (AAC) blocks: a revolution building material in construction industry. Int. J. Sci. Technol. Manage. 5 (2016).

10. Brazilian Association of Technical Standards. NBR 13438: (2013) Autoclaved concrete blocks - Requirements. 2 ed. Sao Paulo: ABNT

11. Bhosale, A.; Zade, N.P.; Davis, R.; Sarkar, P. (2019) Experimental investigation of autoclaved aerated concrete masonry. J. Mat. Civil Eng. 31 [7], 1-11. https://doi. org/10.1061/(asce)mt.1943-5533.0002762.

12. Gálvez, J.C.; Reyes, E.; Casati, M.J. (2010) Estudio de la fisuración de la fábrica de ladrillo con un modelo de fisura cohesiva. Mater. Construcc. 61 [303], 431-449. https://doi. org $/ 10.3989 / \mathrm{mc} .2010 .57910$.

13. Thomaz, E. (1989) Broken in Buildings: causes, preventions and recovery. São Paulo: PINI: Polytechnic School of the State of São Paulo: IPT (1989).

14. Thomaz, E.; Sousa, H.; Roman, H.; Morton, J.; Silva, J. M.; Corrêa, M.R.S.; Pfeffermann, O.; Lourenço, P.B.; Vicente, R.S.; Sousa, R. (2014) Defects in Masonry Walls.: Guidance on Cracking: Identification, Prevention and Repair. Rotterdam, NED: Cib Commission W023, (2014).

15. Caporrino, C.F. (2015) Pathology of anomalies in masonry and mortar coatings. São Paulo: Pini, (2015)

16. Brasil. C. E. G. de A. CBCS - Brazilian Council for Sustainable Construction (Org.) (2014) Aspects of sustainable construction in brazil and promotion of public policies: subsidies for the promotion of sustainable sonstruction. São Paulo: Ministry of the Environment.

17. Abbate, V. (2003) Connecting the walls with pillars needs reinforcement. TECHNE - PINI (2003).

18. Thomaz, E.; Filho, C.V.M.; Cleto, F.R.; Cardoso, F.F. (2009) Code of practice \#1: block sealing masonry. São Paulo: IPT Institute of Technological Research of the State of São Paulo.
19. Brazilian Association of Technical Standards. NBR. 14956-1: (2013) Autocled concrete blocks - Execution of masonry without structural function, Part 1: Procedure with industrialized adhesive mortar. 2 ed. São Paulo: ABNT.

20. Brazilian Association of Technical Standards. NBR. 149562: (2013) Autoclaved concrete blocks - Execution of masonry without structural function, Part 2: Procedure with conventional mortar. 2 ed. São Paulo: ABNT.

21. Brazilian Association of Technical Standards. NBR NM 248: (2003) Aggregates - Determination of particle size composition. Rio de Janeiro: ABNT.

22. Brazilian Association of Technical Standards. NBR NM 52: (2009) Aggregate - Determination of specific weight and apparent specific weight. Rio de Janeiro: ABNT.

23. Brazilian Association of Technical Standards. NBR NM 53: (2009) Aggregate - Determination of specific weight, apparent specific weight and water absorption. Rio de Janeiro: ABNT.

24. Brazilian Association of Technical Standards. NBR. 6118 (2014) Design of concrete structures - Procedure. 3 ed. Rio de Janeiro: ABNT.

25. Brazilian Association of Technical Standards. NBR 13440: (2013) Autoclaved concrete blocks - Test methods. 2 ed. São Paulo: ABNT.

26. Brazilian Association of Technical Standards. NBR. 13279: (2005) Mortar for laying and coating walls and ceilings Determination of load strength in bending and compression. 2 ed. Rio de Janeiro: ABNT.

27. Brazilian Association of Technical Standards. NBR. 13277: (2005) Mortar for laying and coating walls and ceilings - Determination of water retention. 2 ed. Rio de Janeiro: ABNT.

28. Brazilian Association of Technical Standards. NBR. 13276: (2016) Mortar for laying and coating walls and ceilings Determination of consistency index. 3 ed. Rio de Janeiro: ABNT.

29. Brazilian Association of Technical Standards. NBR 16868-3: (2020) Structural masonry - Part 3: Test methods. 1 ed. Rio de Janeiro: ABNT.

30. Alvarenga, R.C.S.S. (2002) Theoretical-experimental analysis of structures composed of steel gantries filled with Autoclavated Autoclaved Concrete masonry. (2002). 342 f. Thesis (Doctorate) - Structural Engineering Course, São Carlos School of Engineering - EESC/USP, São Carlos.

31. Lee, Y.H.; Shek, P.N.; Mohammad, S. (2017) Structural performance of reinforced interlocking blocks column. Construc. Build. Mat. 142, 469-481. https://doi.org/10.1016/j. conbuildmat.2017.03.110

32. Pozo, E.R.; Calzada, M.J.C.; Ruiz, J.C.G. (2008) Experimental scale model study of cracking in brick masonry under tensile and shear stress. Mater. Construcc. 58 [291], 69-83. https://doi.org/10.3989/mc.2008.v58.i291.108.

33. Zanotto, E.D.; Migliore Jr, A.R. (1991) Mechanical properties of ceramic materials: an introduction. Ceramic. 37 [247], 7-16. University of São Carlos - UFSCar.

34. Raj, A.; Borsaikia, A.C.; Dixit, U.S. (2020) Bond strength of Autoclaved Aerated Concrete (AAC) masonry using various joint materials. Journ. Build. Eng. 28, 101039. https://doi. org/10.1016/j.jobe.2019.101039. 